\title{
Pluralism in Agricultural Extension in India: Imperatives and Implications
}

\author{
V.K. Sajesh ${ }^{1 *}$, R.N. Padaria ${ }^{2}$ and V.V. Sadamate ${ }^{3}$ \\ ${ }^{1}$ Scientist (Agricultural Extension), EIS Division, ICAR-CIFT, Cochin-29, Kerala, India \\ ${ }^{2}$ Principal Scientist, Division of Agricultural Extension, ICAR-IARI, New Delhi-12, India \\ ${ }^{3}$ Former Advisor (Agriculture), Planning Board, Government of India, India \\ "Corresponding author: sajeshvk@gmail.com
}

\begin{abstract}
Indian extension system is said to be pluralistic in nature with number of agencies involved in delivery of extension services. There are public, private and third sector actors along with information communication technology (ICT) based initiatives proactively involved in information and technology dissemination in agriculture and allied sectors. Some of the actors are involved in the provision of support services also. It has brought added responsibility to public extension like quality assurance along with provision of technical backstopping, and ensuring coordination between different actors in pluralistic extension system. This article tries to reflect on the imperatives for and major actors of pluralistic extension system in India as well as its implications.
\end{abstract}

Keywords: Agricultural extension, pluralism, convergence

Pluralism in agricultural extension - the existence of variety of agencies, service providers, models and institutional arrangements (public, private, community based, NGOs etc.) catering to the information, advisory and support service needs of farmers-is a reality in Indian context. The heydays of public extension system are over and in the present day Indian context, extension is a complex web of many actors in agricultural innovation system. The reports of situation assessment surveys (2005 and 2014) conducted by National Sample Survey Office (NSSO), an organization under the aegis of Government of India, revealed the extent of pluralism in sources of information accessed by farmers. NSSO (2005) has pointed out that maximum information accessed by farmers was from other progressive farmers $(16.7 \%)$, followed by input dealers $(13.1 \%)$ and radio $(13 \%)$.

The 2013 survey of NSSO once again highlighted the prominence of farmer to farmer exchange of information in Indian agriculture. Traditional and modern ICTs also assume important role among information sources of Indian farmers. The concept of pluralism yoke together the contradictions like complexity of extension landscape generated by the multitude of actors on one hand and diversity needed in extension to address the wide range of farmers and farming situation on other hand.

Since the pluralism has become the norm of India's extension the next question is to harness the synergy of various actors to optimize their contribution towards the welfare of farming community. Since a large numbers of actors are involved in the provision of information advisory and support services to the farmers, integrating their activities across the value chain is important. Sulaiman et al. (2012) have observed that pluralism has brought additional manpower and resources for extension and advisory services (EAS) and also brought new knowledge, skills, and expertise. However it also brought additional challenges of ensuring quality, providing technical backstopping, and ensuring and synergy between diverse EAS providers. Importance of the idea of convergence takes centre stage in 
this context. Convergence is not about complete collaboration among various agencies, but their involvement in required and expected level across the chain, from production to marketing.

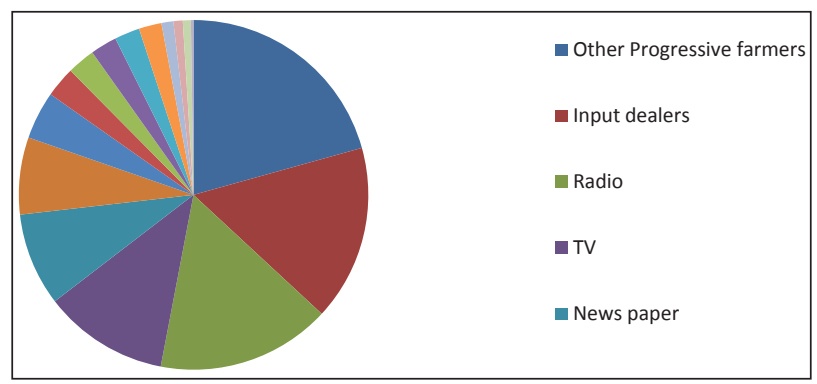

Fig. 1: Proportion of households accessing different sources of information (NSSO, 2005)

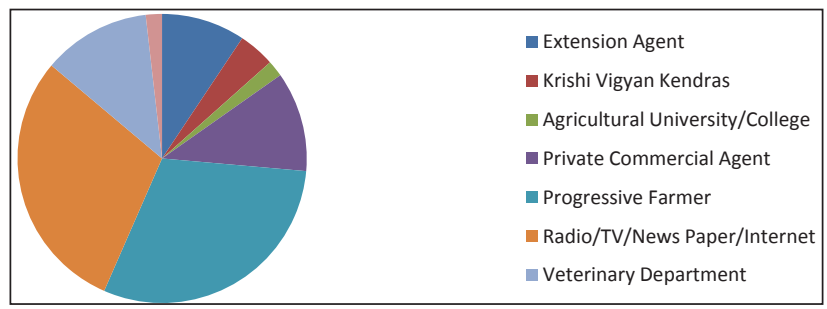

Fig. 2: Proportion of households accessing different sources of information (NSSO, 2014)

(Source: NSSO, 2014).

Convergence can be defined as the strategic and coordinated policy decisions and program actions in multiple sectors to achieve a common goal. It is a complex interplay of a multitude of actors, decisions, and resultant actions, which requires unpacking of the different ways in which decisions and actions by specific actors can either enhance or impede the process. Most important issue is to see whether convergence is achieved in real sense as well as its operationalization at grass root level.

\section{Pluralism in agricultural extension: Imperatives}

Public extension system in India as well as in many parts of the country has been criticized for being: inefficient and ineffective; lacking clear objectives, motivation and incentives; being poorly managed and not accountable to clients; and lacking in relevant technologies (Rivera 1991). In India also, investment in extension continued to be inadequate for quite a long time.

A disaggregated analysis of the growth in the real expenditure in extension activities reveals that during the period between 1995-96 to 2004-05, the real extension expenditure has suffered a negative growth in case of crop sector.

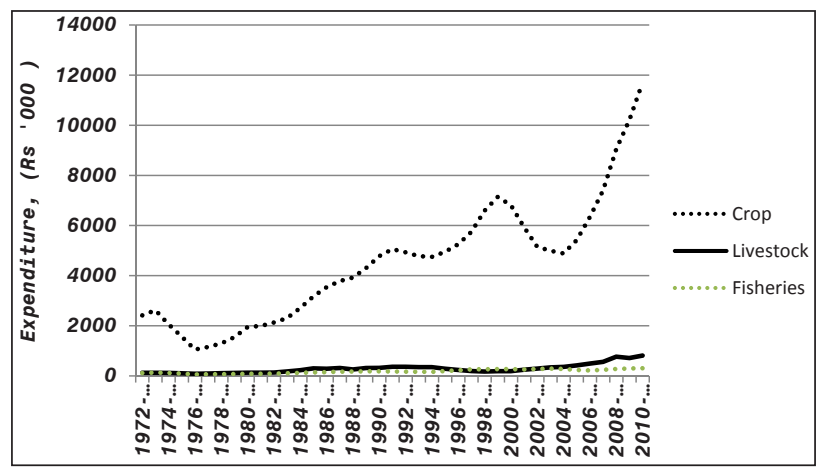

Fig. 3: Trend in Extension Expenditure in India, 19723 to 2010-1, real price (2004-5 base)

(Sajesh and Suresh, 2016).

Moreover, many organizational issues like inadequate staff numbers, low partnerships, and continued top-down linear focus to extension also hinder the functioning of public extension system. (Babu et al. 2013). Non public sector agencies like input agencies, agri-business houses, agro-processing firms, farmer organisations and producer co-operatives, multinational companies, non-governmental organisations (NGOs), media and web based agri-service providers, agriconsultancy providers, financial agencies involved in rural credit delivery, informal extension agents such as progressive farmers and local dealers etc who were involved in agricultural and rural development activities in varying extent for long (Chandra Gowda, 2001; Sulaiman, 2003) slowly rose to prominence and received policy level support to fill up the vacuum created by the public extension. Private extension providers gained more ground with diversification and commercialization of agriculture. Sulaiman and Sadamate (2000) has observed from their study that almost half of the farmers expressed their willingness to pay for extension services, the perceived reason being diversification towards non food crops and lack of required information with concerned line departments. Further, the challenges posed by liberalization policies, especially like reduction in farm subsidies, enhancing market access and elimination of non tariff trade barriers, use of sanitary and phyto-sanitary measures, extension delivery to the disadvantaged areas/groups, etc. demands the enhancement of competitiveness of 
farming communities. This, in turn require variety of information, advisory and support service needs, which cannot be handled by public system alone.

The widespread availability and convergence of information and communication technologies (ICTs) - computers, digital networks, telecommunication, radio, television, print/social media etc., in recent years have led to unprecedented capacity for dissemination of knowledge and information to the rural population (Sulaiman,2003). ICT based initiatives, with their power to overcome the physical barriers and to reduce time and cost in information dissemination, are evolving over years with advancements in technology development.

Vast diversity in agro-climatic conditions and natural resource base, policy environment and uneven regional development pose great challenge to traditional public extension system which is already constrained with human, financial and infrastructural limitations. Chand et al. (2011) have argued for a regionally differentiated strategy for future growth and development of the agriculture sector in the country. A specific concern is extension strategies needed for rain fed areas which supports nearly $40 \%$ of India's estimated population of 1210 million (Sharma, 2011). Moreover, the mandates of agricultural extension were found to be ever increasing, with the emergence of new challenges being faced by agricultural sector like huge yield gap; huge post harvest loss; climate change related risks and vulnerabilities; continuing land fragmentation; emergence of large scale agri-food retails; declining natural resources base; gender concerns in agriculture; bringing indigenous technical knowledge and farmer led innovations into the mainstream etc. Developing a blue print for addressing these diverse challenges will be a futile attempt. Rather, extension should look for a 'best fit' approach (Birner et al. 2006). Farmers can only exercise choice of such an approach if there is a range of service providers to choose from (Rivera and Alex, 2004; Chipeta et al. 2008).

\section{Major Actors in Pluralistic extension System in India}

\section{Public sector}

Since agriculture is a state subject, state departments of agriculture/horticulture/, animal husbandry are the major agencies for the provision of agricultural extension. The mode of operation may vary from state to state. At district level ATMA is functioning as a registered society of all major stakeholders in the agriculture and allied activities with the intention to act as a platform for their convergence at district level. It also intent to leverage the potential of agri-entrepreneurs, para professionals, custom hiring service providers, input dealers and extension workers in non governmental organizations to supplement the effort of public extension functionaries (DAC, 2014).

There are 62 SAUs and 100 ICAR institutes in the country. Though their mandates involve extension in addition to research and teaching(in case of SAUs), the outreach is mainly limited to the villages in their proximity, primarily to demonstrate the technology options suiting the micro agro situations. Some institutes like Indian Agricultural Research Institute (IARI),New Delhi have tried to overcome this by forging collaboration with Non Governmental Organizations, other ICAR institutes/ SAUs and Postal department to increase the spread of institute technologies. Krishi Vigyan Kendras are the extension wings of ICAR at district level with major mandate of technology assessment and demonstration for its application and capacity development. The KVKs, with six to seven subject matter specialists, also provide need based and skill oriented vocational training to the farmers and field level extension workers. At present there are $660 \mathrm{KVKs}$ in the country. The ICAR has also initiated Agricultural Technology Information Centers (ATIC) in selected ICAR institutes and State Agricultural Universities to function as a single window to disseminate the technologies developed in the institute/University. ATICs have been in operation since 2000.

Commodity boards like rubber board, coffee board, spices board, coconut development board etc., are providing support to farmers in the form of technical advises, supply of seeds of improved varieties, soil testing \& fertilizer advisory, product quality \& analytical testing, credit linked subsidies, market promotion, training, need based research, accreditation of input providers etc. Some of the services provided attract a nominal charge as in the case of coffee board (Coffee board, 2011). 


\section{Private Extension}

Status and coverage of private extension agencies in India is not well documented. Private sector enterprises get involved in the extension for simple reason that this kind of involvement will increase their profit and enhance their ability to survive (Rogers, 1987). Input dealers, Agri business firms and agricilinic and agri business centres are the major actors in the sphere of private extension.

There are around 0.3 million agro-input dealers (those dealing with seeds, fertilizers, pesticides and agro-machinery) operating in nukes and corners of the country (DAC, 2014). The situation assessment survey conducted by NSSO (2005) has revealed that input dealers are one of the most important sources of information for farmers. A comparison of human resource intensity of public extension system and input agency system (taking fertilizer dealers as proxy) across the selected states reveals that input (fertilizer) dealers have more intensive presence in most of the states (Table 1), which in turn make them more accessible to farmers. Except Assam, Chattisgarh, Jammu and Kasmir, Jharkand, Kerala and Uttarakand, in all other states number of operational holdings per extension personnel is more than that of number of holdings per fertilizer dealers. Similar pattern is observed when net cropped area is used instead of number of operational holdings. The intensive presence of input agencies and their role in information delivery have been noted by policy makers and it was recommended to harness their potential for increasing the efficiency of extension system.

Table 1: Human Resource Intensity: Public extension Vs. Input agency system

\begin{tabular}{ccccc}
\hline \multirow{2}{*}{ State } & \multicolumn{2}{c}{$\begin{array}{c}\text { Number of } \\
\text { Operational Holdings } \\
\text { per }\end{array}$} & $\begin{array}{c}\text { Net Cropped Area } \\
\text { per }\end{array}$ \\
\cline { 2 - 5 } & $\begin{array}{c}\text { Extension } \\
\text { personnel }\end{array}$ & $\begin{array}{c}\text { Fertilizer } \\
\text { Dealer }\end{array}$ & $\begin{array}{c}\text { Extension } \\
\text { Personnel }\end{array}$ & $\begin{array}{c}\text { Fertilizer } \\
\text { Dealer }\end{array}$ \\
\hline Andhra & 3162 & 1622 & 2608 & 1338 \\
Pradesh & 979 & 3707 & 991 & 3752 \\
Assam & 1583 & 777 & 553 & 272 \\
Bihar & 869 & 1539 & 1092 & 1933 \\
Chattisgarh & 1353 & 509 & 2799 & 1053 \\
Gujarat & & & &
\end{tabular}

\begin{tabular}{ccccc} 
Himachal & 886 & 448 & 499 & 252 \\
Pradesh & & & & \\
Harayana & 536 & 324 & 1184 & 716 \\
J\&K & 249 & 664 & 127 & 339 \\
Jharkhand & 656 & 1388 & 364 & 770 \\
Karnataka & 2428 & 937 & 3154 & 1217 \\
Kerala & 1737 & 2562 & 531 & 783 \\
Madhya & 823 & 945 & 1387 & 1592 \\
Pradesh & 869 & 688 & 1105 & 875 \\
Maharashtra & 1230 & 1319 & 1477 & 1584 \\
Odisha & 753 & 117 & 2982 & 461 \\
Punjab & 1254 & 749 & 3194 & 1908 \\
Rajasthan & 976 & 817 & 606 & 507 \\
Tamil Nadu & 1767 & 776 & 1265 & 555 \\
Uttar & 885 & 1004 & 731 & 829 \\
Pradesh & 1156 & 548 & 859 & 407 \\
Uttarakhand & 1156 & 790 & 1187 & 811 \\
West Bengal & & & \\
Total & & & & \\
\hline
\end{tabular}

Notes: The data number of operational holding, net cropped area and number of extension personnel corresponds to the years 2011, 2008 and 2012, respectively.

Source: Computed by the authors using information from Sajesh and Suresh, 2016., Agricultural Census, 2011 and Department of Fertilizers, 2015.

Besides, Input agency level involvements, many companies have imitated extension programmes at their own level or in collaboration with state departments, but the intensity varies between companies. Rallis India, a subsidiary of Tata Chemicals Ltd. (TCL) has initiated "Samrudh Krishi" programme to impart agricultural knowledge to farmers. Tata Kisan Sansar-the rural outreach business model of TCL-is a network of nearly 600 farmer resource centres functioning in a hub and spoke model. The centres, along the provision of wide range of inputs also provide agricultural services such as soil testing, crop advisory and foliar application services. Hariyali Kisan Bazaars (HKB), a network of agri-input retail stores were initiated by DCM Shriram Consolidated Limited (DSCL) to meet varying requirements of farmers including technical support as well as diverse range of agri-inputs. Godrej Aadhar, the agri-services cum retail initiative of Godrej Agrovet has initiated 'best practices' programs for different crops grown in its region of operations. Indofil, manufacturers and 
exporters of agro-chemicals, carries out a number of activities like demonstrations, crop care training programmes, village adoption programme, farmers' education tour etc.

Many agribusiness firms involved in processing and distribution provide technical support to farmer to ensure assured supply and quality. Classic case is of ITC' (Indian Tobacco Company) e-chaupals, which are basically rural internet kiosks operated by a trained local farmer (sanchalak) based on transaction based income. The e-choupal, besides providing access to information on weather, market prices, prices offered by ITC and scientific farm practices, also provide a platform which enables direct transaction among farmers and processors. Contract farming approach has been practiced by many agri-business firms to ensure uninterrupted supply of required amount of farm produces. Under resource providing contracts there are provision of the farming inputs namely, seeds, fertilizer, advisory and credit. (Swain, 2008).PepsiCo was a pioneer of contract farming in crop sector. They partnered with farmers in Punjab for contract farming of crops like tomato and potao (FAO, 2015).

Initiation of Agri-clinics and Agribusiness Centres (AC\&ABC Scheme) was the conscious attempt of the government to promote private sector initiatives with an intention to supplement the efforts of public extension. Under the scheme unemployed farm graduates were provided two months training and facilitated access to credit to start their own venture. Since its inception in 2002, close to 33 thousand farm graduates were trained and more than 13 thousand ventures were initiated as on 2012 (ACBC, 2013).

\section{Non Governmental Organizations}

Large numbers of NGOs are working in the field of agriculture and rural development in different capacities. Most of the NGOs work in the areas where reach of public and other non public agencies are minimal. Some of the major NGOs in the field of agriculture and rural rural development include BASIX, BAIF, PRADAN, MYRADA, DHAN, Ramakrishna Mission, etc. Most of these organizations are involved in mobilization of farmers and rural women, microfinance, livestock and enterprises development, natural resource conservation and other livelihood intervention activities. In distant and remote areas, where the vacancies in DoA are more, NGOs could be assisted to provide extension services (Sulaiman, 2003). Their flexibility and skill in group formation can be utilized for successful implementation of programmes.

\section{Information and Communication Technology (ICT) based Initiatives}

Information and communication technologies-both traditional and modern-are widely used by public and non public agencies mainly for information dissemination and training. Traditional ICTs like radio, television mainly deal with special agricultural programmes like farm and home, krishi darshan apart from the full fledged Kisan TV which was started recently. Role of print media, besides agricultural magazines (e.g. Karshakasree in Malayalam) and dailies (e.g. Agro One in Marathi), involve articles regional dailies and magazines vernacular languages.

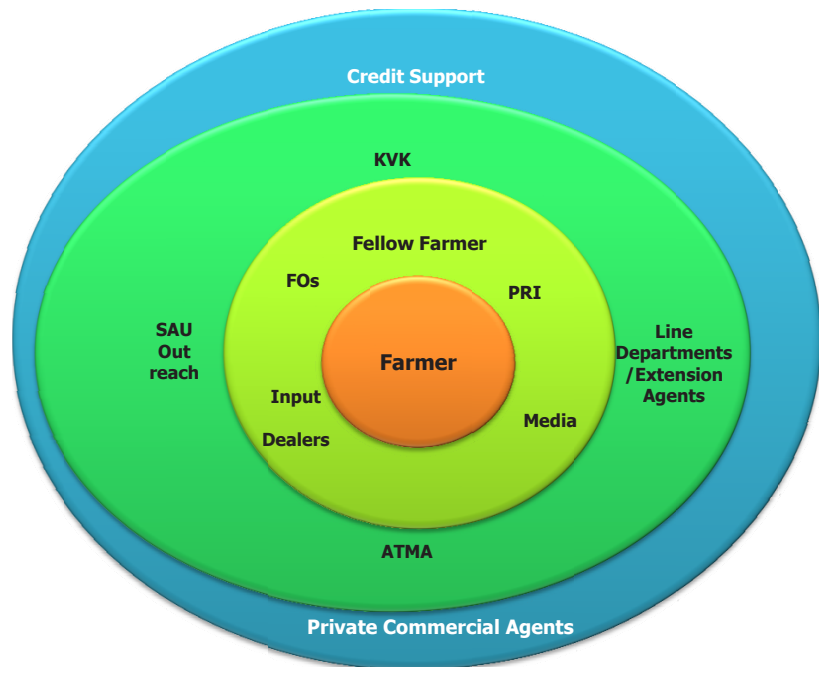

Fig. 4: Schematic Representation of Farmers' Access to Pluralistic Extension Service Providers

Among the newICT based initiatives internet enabled computer centres and portals mainly dealt with information on crop production, weather, government services, agricultural statistics, market price information etc. Videos were used for instructional purpose (e.g. Digital Green) and training (e.g. Video SEWA), while digital photographs of crops were used for expert advise as in the case of e-velanmai. Kisan Call Centres, a government initiative, are meant to provide Answers on specific queries from experts located at call centres and at other locations. Mobile 
phones were used to send messages on weather and prices of commodities in different markets (e.g. Reuters Market Light (RML); IFFCO-IKSL; Tata m-Krishi); but with invention of smart phones, number application with all required information are available (e.g. Agri App). Community Radios deliver wide range of information on rural life, agriculture, forests, health, nutrition, etc. in their proximity (Rasheed, 2011 ). Of late, social media (e.g. Face book, Whatsapp, Youtube etc.) are used in extension for sharing information in text, audio, visual and video formats (Rasheed, 2011). The successful impact made by the ICT projects in certain areas shall have to be replicated for the greater benefit to the farming community in different areas.

\section{Implications}

Pluralistic extension system in India has both pros and cons. While the existence of multiple agencies can address the diverse needs of farming community and complement each other, there are also possibilities of duplication efforts, competition and contradictory information provision. Effective coordination among different agencies and programmes with proper delineation of roles and activities is the need of the hour and the onus mainly rest on the shoulder of public extension system, primarily ATMAs, ATARIs and SAMETIs could provide leads in designing and delivering coordinated extension approach.

\section{Role of Public Extension}

Pluralism has brought added responsibility to public extension like quality assurance along with provision of technical backstopping, and ensuring coordination between different actors in pluralistic extension system. With number of information providers abound; content development, validation of the developed message and prevention of contradictory information provision are the major challenges. Public agencies, especially Krishi Vigyan Kendras (KVKs) in collaboration with ATMA field functionaries can play a major role in forging the network of various actors in research, extension and community domains for mobilsation and validation of context specific information. As public extension is the 'authentic' source of information and the policy instrument, it has to play leading role among the many actors in the pluralistic extension system.. This in turn requires the careful analysis of strengths, limitations, potential of public sector actors to devise further strategies. Besides, enhancement of capacities and resources of public sector agencies to integrate the different models of knowledge and skill available with various actors, public sector also need to play the role of developing the competencies of various actors to improve their performance as well as to delineate their roles to avoid duplication of efforts.

\section{Convergence and coordination}

Of late, convergence of multiple actors in agricultural extension and is being highlighted as the major strategy to the increase the efficiency in service delivery. The major move was initiation of Agricultural Technology Management Agency (ATMA), which is supposed to act as an umbrella for all major stakeholders in the agriculture and allied activities within the district. The Modified Extension Reforms Scheme introduced in 2010 was indented to synergize the interventions under various schemes under the umbrella of ATMA. The initiation of National Mission on Agriculture and Technology (NMAET) with four Sub Missions on Agricultural Extension, Seed and Planting Material , Agricultural Mechanization and on Plant Protection and Plant Quarantine is being envisaged as the further stride in this direction.

Convergence can be of different types viz. Policy level, Resource level and service delivery level (TRIPTI, undated):

(a) Convergence at policy level: It is important in terms of the formulation of common agenda of stake holders and its operationalisation. It form the basis for other levels of convergence

(b) Resource based/Instituional linkage based convergence: It focus on the convergence of human, financial and other resources of different programmes with common agenda. Convergence of developmental departments as in the case of ATMA is an example. Planning for resources is a must requisite in such cases.

(c) Service based/Issue based convergence: It is based on the needs of people in a location for required services (input, technology, extension, marketing, capacity development etc.). 'Convergence 
Table 2: SWOT analysis of pluralistic extension system

\begin{tabular}{|c|c|c|c|}
\hline Strengths & Weaknesses & Opportunities & Threats \\
\hline $\begin{array}{l}\text { 1. Diversity in approaches and } \\
\text { target groups covered }\end{array}$ & $\begin{array}{l}\text { 1. Possibility of duplication of } \\
\text { effort. }\end{array}$ & $\begin{array}{l}\text { 1.Potential to harness the } \\
\text { synergy of all actors through }\end{array}$ & $\begin{array}{l}\text { 1.Lack of effective } \\
\text { coordination among agencies }\end{array}$ \\
\hline $\begin{array}{l}\text { 2. Multiple agencies can } \\
\text { complement and supplement }\end{array}$ & $\begin{array}{l}\text { 2. Provision of contradictory } \\
\text { information and resultant }\end{array}$ & $\begin{array}{l}\text { convergence } \\
\text { 2.Delineation of roles of }\end{array}$ & $\begin{array}{l}\text { 2. Absence of platform for } \\
\text { coordination }\end{array}$ \\
\hline the efforts of each other. & confusion gaps among farmer & each agency/actor to avoid & 3. Efforts of collaboration \\
\hline 3. Non public agencies can & 3. Problem with quality of & duplication/overlaps of efforts & without imbibing the spirit \\
\hline $\begin{array}{l}\text { cater to the demands of } \\
\text { farmers which are of private }\end{array}$ & $\begin{array}{l}\text { messages from non public } \\
\text { agencies }\end{array}$ & $\begin{array}{l}\text { 3. Enable farmers to choose } \\
\text { among different agencies as }\end{array}$ & $\begin{array}{l}\text { 4. Mismatch between } \\
\text { organizational agendas-and }\end{array}$ \\
\hline $\begin{array}{l}\text { good nature. } \\
\text { 4. Help to overcome the }\end{array}$ & $\begin{array}{l}\text { 4. Motives and objectives of all } \\
\text { agencies may not be aligned }\end{array}$ & $\begin{array}{l}\text { per requirement (which in } \\
\text { turn make extension demand }\end{array}$ & $\begin{array}{l}\text { problems due to hidden } \\
\text { agendas }\end{array}$ \\
\hline paucity of human resource in & with farmers. & & 5. Lack of leadership and \\
\hline $\begin{array}{l}\text { public system } \\
\text { 5.Help to address varying } \\
\text { needs of farming community }\end{array}$ & $\begin{array}{l}\text { 5. Making the extension } \\
\text { system more complex }\end{array}$ & $\begin{array}{l}\text { 4. Greater scope for farmers } \\
\text { participation in extension } \\
\text { programmes }\end{array}$ & $\begin{array}{l}\text { conflict resolution mechanism } \\
\text { may hamper effective } \\
\text { collaboration }\end{array}$ \\
\hline $\begin{array}{l}\text { 6. Increase in outreach where } \\
\text { public system is weak }\end{array}$ & & $\begin{array}{l}\text { 5. Public extension can } \\
\text { reorient its role for leading the }\end{array}$ & $\begin{array}{l}\text { 6. Political and economic } \\
\text { aspects preventing effective }\end{array}$ \\
\hline $\begin{array}{l}\text { 7. Provision of newer } \\
\text { technologies and skills to } \\
\text { farmers. }\end{array}$ & & $\begin{array}{l}\text { pluralistic system } \\
6 \text {. Potential to create linkage } \\
\text { of farmers with other actors } \\
\text { across the value chain. }\end{array}$ & $\begin{array}{l}\text { collaboration } \\
\text { 7. Doubt about sustainability } \\
\text { of government promoted } \\
\text { convergence initiatives }\end{array}$ \\
\hline
\end{tabular}

of Agricultural Interventions in Maharashtra's Distressed Districts Project'(CAIM) is an example for issue based convergence The project is implemented by the Government of Maharashtra (GoM) with the support of International Fund for Agriculture Development (IFAD) and the Tata Trusts, in Vidarbha region of Maharashtra state where agricultural distress and farmers' suicides are pressing issues. What required in service level convergence is a value chain perspective. Potential of different actors need to be harnessed across the value chain so that they will complement each other rather than competition. There will be clear cut delineation of role of each actor to have successful coordination.

\section{(i) Farmers Organizations as platforms of} Convergence: Anecdotal evidences point out that government supported convergence initiatives are at policy level or maximum at resource level focusing on sharing of human and financial resources. Also, sustainability of such initiatives is a matter of concern when government support is blocked. Farmers' organizations(community based and commodity based) can act as platforms of convergence, as they are demand driven-based on location specific or crop specific needs- rather than supply driven as in the case of government initiatives. An example is coconut produces collectives in Kerala formed under the guidance of Coconut Development Board. These collectives at village level act as platform for convergence of agencies like State Horticulture Mission, Small Farmers' Agri Business Consortium, State Agriculture University, Central Plantation Crops Research Institute, State Level Research Institutes and the three tier Local Self Government Institutions. Many central sector schemes like RKVY, BRGF, NRLM and MGNREGS are also converged with these collectives (Anonymous, 2013). These collectives are federated into producer federations at 'gram panchayat level' and into producer companies at Tehsil level, improving the sustainability of the collectives.

Vegetables and Fruits Promotion Council of Kerala is another successful example of mobilizing farmers into Self Help Groups (SHGs) to facilitate convergence and federating them for better access to inputs, technology and market. The SHGs form the base units for all the interventions like Extension, Rural Credit, Group Marketing, Participatory Technology Development (PTD), Value Additions and Exports. Group approach further facilitates to train master farmers in each group and marketing through collective of groups. In horticulture sector, Mahagrapes-association of 16 grape growers' cooperative societies- in Maharashtra supplies inputs, technology, and extension services to farmers 
through cooperatives and support the farmers to produce quality output conforming to food safety and quality standards of the importing countries. It provides refrigerated transport and cold storage facilities for farmers by charging a fixed amount (Birthal et al. 2007). These examples illustrate that, farmers' collectives can function as platforms for 'demand based convergence' of various agencies, while federating them in higher level can enhance their competitiveness and sustainability.

(ii) Cost of Convergence: A convergence system will be sustainable only if it is a win-win situation for all the parties and outcome oriented. This in turn requires effective management, quality control, functional instructions down the lines, understanding each other's roles and responsibilities clearly and careful monitoring and regular evaluation. The situation warrants a change in organizational thinking and human resource development of the partnering organization, an added responsibility to Extension training institutes. Another aspect is sourcing out the fund available with public extension system to partnering agencies. In the nutshell, the benefit accrued from the joint effort need to be much higher, so that cost of coordination is justified.

\section{Way Forwards}

1. Pluralistic extension needs to be promoted in agricultural and allied sectors. Role space for each Extension Service Provider (ESP) to be assigned to those agencies having comparative advantage on the basis of 'best actor' scenario.

2. Public sector extension service to work out as above and to play the facilitators and enablers role to streamline, 'lead and supplement 'scenario in a given situation.

3. Generally public sector extension service providers are found to be performing well on backward linkages and private sectors service providers have an advantage on forward linkages. NGOs, CSOs, Community Based Organisations (CBOs) are found to be performing positively in community mobilisation. These may be kept in view.

4. All pluralistic agencies may promote empowered Farmer Organisations (FOs) on commodity basis so as to promote demand driven extension services.

5. All pluralistic agencies to promote Community of Practice (COP) enabling local extension initiatives and responses.

6. Public and private extension service providers have defined roles and one need not necessarily substitute other, rather they should supplement and complement each other.

7. Centrality of pluralistic extension service providers has to be plotted assigning backup roles to other extension service providers (secondary and tertiary) in a given situation.

8. Public and private extension providers could perform better in given situations if their roles are defined as per the priorities reflected in district/ block plans, it would also improve the relevance of extension interventions.

9. Both public and private extension providers may respond to emerging extension needs as per proven expertise, comparative advantage and on the basis of feedback analysis.

In 'mixed economies' like India, where public and non public sector entities exist in competition or cooperation, a pluralism in agricultural extension can be well translated to the welfare of the farmers. Given the scale and complexity of Indian agriculture, with many small farmers, remote regions and varied farming systems, a pluralistic extension system will reach farmers more effectively than a single method of funding and delivery. Opportunity for choosing among competitive service providers notwithstanding, coordination of different actors remains the major challenge. Experiences from the field point out that convergence can be operationalised through farmers' organizations of various formats on demand basis, to be facilitated by both public and private extension service providers. Further, federating them will add to their sustainability.

\section{REFERENCES}

Anonymous.2013. Convergence and Collective Convergent Action. Indian Coconut Journal, January 2013, pp. 4-5.

Babu, S.C. et al. 2013. The State of Agricultural Extension Reforms in India: Strategic Priorities and Policy Options. Agricultural Economics Research Review, 26(2): 159-172. 
Birner, Regina et al. 2006. "From "best practice" to "best fit": a framework for designing and analyzing pluralistic agricultural advisory services worldwide," FCND discussion papers 210, International Food Policy Research Institute (IFPRI).

Birthal, P.S., Jha, A.K. and Harvinder Singh. 2007. Linking farmers to market for high value agricultural commodities, Agricultural Economics Research Review, 20: 425-439.

Chandra Gowda, M.J. 2001. Micro level Opportunities and Challenges for Privatization of Agricultural Extension,in Private Extension in India: Myths, Realities, Apprehensions and Approaches (eds. Chandrashekhara, P), National Institute of Agricultural Extension Management Rajendranagar, Hyderabad, 2001, pp. 18-26.

Chand, Ramesh, Raju, S.S., Garg, S. and Pandey, L.M. 2011. Instability and regional variation in Indian agriculture, Policy Paper 26, 2011.National Centre for Agricultural Economics and Policy Research, New Delhi.

DAC. 2000. Policy framework for agricultural extension (draft). New Delhi: Extension Division, Department of Agriculture and Co-operation, Ministry of Agriculture, Government of India.

DAC. 2014. Guidelines for Operationalization of Diploma in Agricultural Extension Services for Input Dealers (DAESI) Program, Department of Agriculture \& Cooperation Ministry of Agriculture Government of India.

FAO. 2015. The potato supply chain to PepsiCo's Frito Lay, Food and Agriculture Organization of United Nations.

NSSO. 2005. Situation Assessment Survey of Farmers - Some aspects of Farming, 59 ${ }^{\text {th }}$ Round (January - December 2003). National Sample Survey Organization (NSS), Report No. 496(59/33/3). Ministry of Statistics and Programme Implementation. Government of India, New Delhi.

NSSO. 2014. Key Indicators of Situations of Agricultural Households in India. $70^{\text {th }}$ round (January-December 2013), National Sample Survey Organization (NSS), New Delhi: Ministry of Statistics and Programme Implementation.
Rivera, W.M. 1991. Agricultural Extension Worldwide: A Critical Turning Point in Agricultural Extension: Worldwide Instituional Evolution and Forces of Change (eds. Rivera, W.M and Gustafson). Elsevier, London, pp. 3-11.

Sajesh, V.K. and Suresh, A. 2016. Public Sector Agricultural Extension in India-A Note. Review of Agrarian Studies. 6(1), http://www.ras.org.in/public_sector_agricultural_ extension_in_india

Sharma, K.D. 2011. Rain-fed agriculture could meet the challenges of food security in India, Current Sciences, 100(11).

Sulaiman, V.R. 2003. Innovations in agricultural extension in India, SD Dimensions, June 2003.

Sulaiman, V.R. 2003. Agriculture extension: Involvement of private sector, Occasional Paper - 29, NABARD, Mumbai, 2003.

Sulaiman, V.R. and Sadamate, V.V. 2000. Privatising Agricultural Extension in India, Policy Paper 10, 2000, National Centre for Agricultural Economics and Policy Research, New Delhi.

Sulaiman,Rasheed, V., Kalaivani, N.J., Nimisha Mittal and Ramasundaram, P. 2011. ICTs and Empowerment of Indian Rural Women What can we learn from on-going initiatives? CRISP Working Paper 2011-001, Centre for Research on Innovation and Science Policy (CRISP), Hyderabad, India, 2011.

Swain, Braja Bandhu. 2008. The role of contract farming in agricultural development in globalised world: an institutional economics analysis, Centre for Development Studies, Trivandrum, kerala, India.

TRIPTI. Undated., Guidelines for Convergence, Orissa Poverty Reduction Mission TRIPTI, pp. 8-9. 
